\title{
VÁLTOZATOK A KÖZÉPSZINTRE, AVAGY A MAGYAR KÖZÉPSZINTTELENSÉG
}

\author{
(Variations for Intermediate Level \\ or the Lack of Hungarian Intermediate Level)
}

\section{ZONGOR GÁBOR}

\section{A rendszerváltás elôtti időkről röviden}

A magyarországi politikai rendszerváltás kőzigazgatásra - azon belül is elsődlegesen a középszintủ igazgatásra - gyakorolt hatásának bemutatása és értékelése nélkülözhetetlenné teszi, hogy ha csak jelzésszerüen is, de röviden bemutassuk a közigazgatás 1990 elôtti állapotát. Az egypártállami társadalomirányítási rendszer legföbb jellemzője a társadalmi valóság legszélesebb kőrére kiterjedő hatalom koncentráció és a párt által vezényelt szigorú hierarchikus dőntési struktưra volt. A pártállami rendszerben az államigazgatás politikának kiszolgáltatott és azt kiszolgáló jellege mindvégig egyértelmüen érvényesült, ugyanakkor az 1971-es tanácstörvényt ${ }^{1}$ kővetően a helyi államigazgatás - mint sajátos alrendszer - részleges fuiggetlenségi törekvése a politikai hatalom diktatórikus erejének fokozatos csőkkenése révén egyre határozottabban erősődőttt.

1971-ben megszüntek a járási tanácsok, melynek révén a járási pártirányítás formálisan létezơ tanácstestületi „legitimációs” bázisa felszámolásra került. Ezzel egyidejüleg csőkkent a járások száma és súlya is. A járás ekkortól a telepulések és a megye közötti korlátozott - fokozatosan csökkenö - jogosítványokkal rendelkezö sajátos kőzvetítő igazgatási egységgé vált. Így a települések mindennapi életébe kézi vezérléssel beavatkozó járási hatalom megszünése lassacskán nơvelte a települések szabadabb mozgását. Ezzel párhuzamosan a törvényi szabályozás életre hivta a városkörnyékiség kategóriáját ${ }^{2}$, melynek következtében a város és kőzvetlen vonzáskőrzetébe tartozó telepúlések között sajátos, igazgatási jellegú kapcsolat alakulhatott ki.

A települések jogállásában e változások jogi értelemben módosulást ugyan nem eredményeztek, viszont új lehetóségeket biztositott a települési érdekek megyei szintủ kifejezésére, a közvetlenebb település-megye kapcsolatok kialakulására, azon túlmenően, hogy a felettes pártirányítás hatása lényegesen csőkkent.

A járási irányítás alól való felszabadulással a városkörnyéki települések a városokkal kerültek közös érdekkörbe, miközben az igazgatási feladatok racionalizálására is sor kerülhetett. Ebben az átmeneti, sok tekintetben kísérleti időszakban megjelent a város és - a vonzáskörzetébe tartozó - kőzség közőttti társulás lehetősége és a kőzős fejlesztések gyakorlata. 
A helyi igazgatási rendszer változási folyamatában a következő korszak 1984. január I-jével vette kezdetét, amikor a járások, mint igazgatósi kategóriák teljesen megszüntek.

A járások kiváltása - a központi döntés eredményeként - a városkörnyékiesítés általánossá tételével történt, vagyis az addigi fokozatos építkezés felgyorsult, és valamennyi település végül is besorolódott valamelyik városkörnyékbe. Ennek következtében a megyék közigazgatási térképe a városkörnyékek vonatkozásában formálisan csaknem megegyezett az 1950-es járási struktúrával. Lényegét tekintve azonban teljesen új helyzet alakult ki azáltal, hogy a községek, mint települések (közös tanácsok esetében település-egyưttesek) érdekképviseleti fórumává elvileg a megyei tanácsok váltak, és létrejött az ún. két- és félfokú igazgatás rendszere ${ }^{3}$ (Zongor 1984a; 1984b). Jelentősen növekedett a települések igazgatási önállósága és hatásköre.

Változás történt a települési érdekek helyi érvényesitésében is az elöljáróságok ${ }^{4}$ létrejöttével. A közös tanácsokba tartozó településeken megválasztott tanácstagok viszonylagos önállósággal rendelkezõ elöljáróságokat alkothattak. Ez a lépés elindította az elkülönülő települési érdekek újbóli megfogalmazásának lehetőségét. A rendszer továbbra is érvényestulö központositó jellegéböl adódóan természetesen a települések önálló gazdálkodásáról nem beszélhettünk. A megyék pénzelosztó szerepét negatívan befolyásolta a sok tekintetben torz és centralizáló jellegũ országos településfejlesztési koncepció ${ }^{5}$. (A szerepkör nélküli települések számára az elözőekben irt változások nem jelentettek, nem jelenthettek valóságos változtatási lehetőséget!)

Az állampárti rendszer gyengülését, haldoklását jól érzékeltette az 1985-ös országgyülési választás. Az ekkor - a demokrácia látszólagos növelése céljából - bevezetett formálisnak tủnő kötelező kettős jelölési rendszer, ha kis mértékben is, de lehetőséget biztosított a helyi népítéletre, és a legnegativabb megyei politikai közszereplök választópolgárok általi leváltására ${ }^{6}$.

A nyolcvanas évek második felében a politikai hatalom bomlását kihasználva az államigazgatás fokozta oonállóságát és a napi politikai hatások alóli fủggetlenedését. $\mathrm{Az}$ utolsó tanácsciklusban a települések jelentős részében már olyan helyi politikusok kerültek vezető pozícióba, akik változtatni akartak a fennálló rendszeren. Ekkorra a telepuủések zömében a helyi politika meghatározó szereplỏjévé a párttitkárral szemben a tanácselnök vált.

Ebben az időszakban egyre erőteljesebben jelentek meg az önállósági törekvések, és a központi elosztásnál is a normativ újraelosztás rendszere lett a meghatározó. $A$ közigazgatás függetlensége, legalábbis politikai értelemben, a Németh-kormány ideje alatt érte el eddigi legnagyobb szabadságfokát. A bizonytalan és ingatag politika önmagával volt elfoglalva, melynek következtében az államigazgatás alapvetöen szakmai szempontok alapján tehette a dolgát. Ekkorra kialakult és felnőtt a településeken és a megyékben is egy jól felkészült, kellỏ szakmai hivatástudattal rendelkező igazgatási szakember gárda. Rendszeressé vált önszerveződő viták, szakmai képzések és továbbképzések is segítették az igazgatás szervezettségét, felkészültsé- 
gét, és erösítették önállóságát. Ebben az időszakban tényleges lehetősége nyílt a szakmának arra, hogy a jogalkotásra is hatással legyen.

$\mathrm{Az}$ alkotmányos rendszerváltást elökészítő Németh-kormány az ellenzéki pártok nyomására is tekintettel hozzálátott a hatalom lebontásához és a közigazgatás depolitizálásához. Ennek révén megindult a jogszabályok átfogó deregulációja, megszünt a végrehajtó bizottságok kettős alárendeltsége, melynek következtében elvileg megvalósult a helyi tanácsok szervezeti fủggetlensége. Tovább erösödtek a települési önállósulási törekvések, az utolsó hónapokban már valódi érdekưtközések színterévé vált az addig formálisan - deklaratív jelleggel müködö - megyei tanács is.

$\mathrm{Az}$ időközi választások lehetővé tették, hogy a tanácstestületekben is megjelenjenek az újonnan létrejött pártok képviselói. Megnyílt a helyi társadalmi nyilvánosság. Mindezek természetesen nem pótolták, nem pótolhatták a tényleges plurális érdekképviseletet.

Az egypártállami hatalomgyakorlás rendszerében a megyei szint 1950-től változó intenzitással ugyan, de mindvégig a központi politikai hatalom által meghatározottan a centralizációs törekvések szolgálatában állt. A megyei tanácsok szakigazgatási szervezeti rendszere is jórészt leképezte a mindenkori kormányzati ágazati struktúrát. Az ágazati irányítás rendszere mindvégig meglehetősen eröteljesen érvényesült. A megyei tanácsok átfogó strukturális átalakítására - kampány jelleggel ${ }^{7}$ - közvetlenül a rendszerváltást megelőzöen került sor, és tényleges hasznosulását ma már nem lehet megitélni. A telepulési ơnállósulási törekvések képviselői szempontjából a megyék mindvégig a központositó hatalom felszámolandó bástyái voltak. A nyolcvanas évek második felében már a nagyobb - elsỏdlegesen a megyeszékhely városok sok esetben megfelelö politikai háttérrel sikerrel érvényesítették a települési érdekeket a megyei szándékokkal szemben.

$\mathrm{Az}$ 1990-es országos és helyi képviselöválasztások mintegy föpróbájakẻnt zajlott le 1989 novemberében az ún. négy igenról szóló népszavazás, melynek lebonyolítását az átmenet nehézségei ellenére zavartalanul végezte az igazgatási apparátus (Zongor 1990). A helyi közigazgatás felkészültségét és pártpolitika-mentességét jól példázta a rendszerváltó választások zökkenömentes és törvényes lebonyolítása.

Így jutottunk el a magyarországi politikai rendszerváltáshoz, amely a közigazgatás szervezeti egységeiben és leginkább struktúrájában mélyreható és jelentős változásokat idézett elö.

\section{A jelenlegi helyzet kialakulásának története}

A politikai rendszerváltás folyamatában kétségtelenül az egyik legjelentősebb és legizgalmasabb változást a helyi önkormónyzatokról szóló törvény ${ }^{8}$ idézte elő. A törvény alkotói elsődlegesen a települések ,felszabadítására” törekedtek, míg a középszint problematikájánál az eltérỏ nézeteket feloldó kompromisszum kialakitására és nem pedig a mükődőképesség vizsgálatára koncentráltak. Jelentős politikai vita alakult ki arról, hogy a diktatórikus hatalomgyakorlás bünbakjaként megjelenített 
megyei tanácsok helyébe milyen típusú közigazgatási egység lépjen. Végül is a tipikus kecske és káposzta helyzet alakult ki azáltal, hogy az erősen legyengített megyei önkormányzatok létrehozatala mellett viszonylag erős állami igazgatási szervezeti rendszer kiépítéséröl döntött a Parlament. Ezen túlmenően, ugyancsak a települési lobbi nyomásának köszönhetően, a középszinten újabb szereplő - sajátos kakukkfióka jelent meg a megyei jogú város kategória megteremtésével.

A többszereplös középszint viszonylag lassan és fokozatosan alakult ki. 1990-ben megyei szinten érdemi változások nem történtek, ugyanis a megyei közgyülések alakuló ủléseire többnyire az év utolsó napjaiban került sor a sajátos közvetett választási eljárásnak köszönhetően (Zongor 1991), ezért a - „választott” testületek nélkül maradt - megyei tanácsi apparátus átmenetileg törvényi felhatalmazás nélkül szakmai tisztességböl látta el a közigazgatási feladatokat.

A magyar közigazgatás máig ható leglényegesebb megoldatlan problémája az államigazgatási, illetöleg az önkormányzati közigazgatás egymástól való egyértelmú lehatárolásának kérdése. Az 1990-es önkormányzati törvény a megyei önkormányzati feladatokat jelzésszerúen fogalmazta meg, viszont a szabályozásból egyértelmüen kiderült, hogy az új típusú megyei önkormányzatok feladata - a szubszidiaritás elvének egyoldalú túlhangsúlyozásával - jószerivel csak középfokú közszolgáltató intézmények fenntartására szorítkozott, legalábbis a szabályozás szintjén. A hatásköri törvény ${ }^{9}$ egyértelmüsítette az önkormányzati és állami feladatok elhatárolását megyei szinten, melynek eredményeként a megyei önkormányzatoknak valódi közigazgatási hatáskört nem adott a törvényhozó. A sajátosan és tudatosan legyengített megyei önkormányzat kiszolgáltatott és hátrányos helyzetét jól tükrözi, hogy az Alkotmányban deklarált szabály ellenére ${ }^{10}$ egyedül a megyei önkormányzatok nem rendelkeznek adókivetési joggal, mint önkormányzati alapjoggal.

Az önkormányzati törvény középszinten meglehetỏsen formális szempont alapján, és érdemi feladat meghatározása nélkủl létrehozta a megyei jogú város kategóriáját ${ }^{11}$. Az önkormányzati megyén kívưli hasonló joggal rendelkező városok a megyei önkormányzatok mozgásterét tovább gyengitették. A két megyei önkormányzat közötti szembenállás a törvényi szabályozatlanságból adódóan, illetve történeti okokból kezdetektöl kódolva volt. A közigazgatási funkciójától megfosztott megyei önkormányzattól még az illetékbeszedési jog is átkerült a megyei jogú városokhoz.

A középszintú közigazgatás állami szereplöinél is a többpólusúság volt a jellemzö. Egyrészt új szereplőként megjelent a köztársasági megbizotti rendszer, a megbízottak illetékessége két vagy több megyére terjedt $\mathrm{ki}^{12}$. A régiókba kinevezett állami helytartók feladata alapvetően törvényességi ellenórzésre, illetőleg a klasszikus államigazgatási hatáskörökre terjedt ki, viszont kezdetektől fogva politikai szereplöként jelentek meg, és pillanatokon belül éles rivalizálás alakult ki a megyei választott testület és annak vezetöi, valamint a régió fönök között.

Bár a köztársasági megbízottak igyekeztek a megyében tevékenykedö állami és államigazgatási szervek felett irányító pozíciót betölteni, valójában ez csak látszólag sikerült, mivel az erőteljes ágazati szemléletet nem sikerült áttörniük. A hajdan volt megyei tanácsi szakigazgatási szervek helyett folyamatosan jöttek létre a megyei 
dekoncentrált szervek ${ }^{13} .1992$ végére lényegében befejeződött a középszint újra államosítása, vagy másként kifejezve „eldekósítása”.

$A$ középszinten a rendszerváltás leginkább a szervezeti, strukturális változtatások sorozatában jelent meg. Különösebb érdemi elemzés nélkủl döntően politikai indíttatásból került sor a korábbi struktúra teljes szétverésére és új, áttekinthetetlen közigazgatási „,rendszer” kialakítására. A középszint szereplöinek sokaságát jellemezte a szervezetek közötti intézményesített együttmüködés hiánya, melyet megyénként eltérö mértékben a korábbi szakmai és kollegális kapcsolatok igyekeztek elviselhetővé és múködőképessé tenni. Középszinten végül is kétféle önkormányzati szervezet jött létre: a megyei önkormányzat (19) és a megyei jogú város (20); valamint kétféle államigazgatási szervezet: az általános hatáskörü politikai integrátor, a regionalizált köztársasági megbízott (8) és a megyénkẻnt eltérő számú dekoncentrált szervek (28-34).

A szervezeti átalakításon tủlmenően már az 1990-94 közötti kormányzati időszakban is megjelenik a középszint egységeinek újragondolása, és a megyék régiókkal történỏ kiváltásának a szándéka. Az igazgatási régiókkẻnt kialakított köztársasági megbízotti rendszer lett a követendő minta az igazgatási régiók létrehozására. Ugyanakkor látni kell, hogy a regionális közigazgatási szerveknek is kialakult a megyei belső szervezete. Az érdemi, szakmai munka a megyei szerveződésekben zajlott.

Ebben az idöszakban a megyei önkormányzatok viszonylag intenzíven léptek fel helyưuk és szerepưk tisztázása érdekében. Az 1994-es parlamenti választásokat követốen a szakma és a gyakorlat által feltárt változtatási irányok csak kis mértékben, és továbbra is csak deklarációk szintjén valósultak meg. A megyei önkormányzat a törvényben nevesítetten területi önkormányzat lett, viszont hatásköre és önálló forrása tekintetében jelentős érdemi változás nem történt. Visszakerült megyei önkormányzati feladatba a megyei jogú városoktól az illeték kiszabási jog, valamint önkormányzati intézménnyé vált a sportigazgatás ${ }^{14}$ szervezése. Elvileg hatósági hatáskörök címzettjévé váihhattak a megyei fỏjegyzök. A megyei védelmi bizottság elnöke - a KMB-s helyett - a közgyúlés elnöke lett. Ugyanakkor továbbra sem kapta meg a megyei terulletfejlesztés feladatát a megyei önkormányzat, hanem helyette egy új intézmény, a megyei területfejlesztési tanács létrehozását célozta meg az önkormányzati törvény módosítása ${ }^{15}$. A megyei önkormányzat szintjén a leglényegesebb érdemi változás a választás módjában következett be. A tisztán pártelvũ listás választós ugyan megfelelt a közvetlenség kritériumának, viszont nem vette figyelembe a megyei önkormányzatok tényleges feladatkörét és lehetőségeit. Így jöttek létre a hihetetlen erös politikai legitimációval rendelkező megyei politikai testületek (Zongor 1996), amelyek továbbra is döntően intézmény-fenntartási feladatokkal rendelkeztek csupán.

A megyei jogú városok körében további bỏvülés történt azáltal, hogy lakosságszámtól fưggetlenül a megyeszékhely városok is elnyerték a megyén kívüliség lehetőségét. Így a megyei jogú városok száma 22-re emelkedett. Az önkormányzati törvény módosítása érzékeltette a megyei önkormányzat és a megyei jogú város közötti 
ellentétet, viszont a probléma megoldása helyett a problémát megvitató, kötelezően létrehozandó egyeztető bizottság mükődtetéséröl döntött csupán ${ }^{16}$.

A kormányváltással a köztársasági megbízotti intézményrendszer felszámolásra került, megszüntek a megbízottak, és megszüntek a hivatal regionális szerveződései is. A helyükre lépó megyei közigazgatósi hivatalok lényegében ugyanazt a törvényességi ellenőrzési és hatósági feladatot látták el, mint elötte, viszont megszünt a politikai szerepük, így a megyék elsőszámú politikai központja a megyei közgyủlés lett.

E kormányzati ciklus második felétől felerősődőtt az a kormányzati elképzelés, hogy a közigazgatási hivatalok kormányhivatalokká váljanak, és egyben megtörténjen a nagyszámú dekoncentrált szerv felszámolása, ősszeolvasztása, illetve a megyei kőzigazgatási hivatalokba való integrálása. E kormányzati szándék azonban az ágazati minisztériumok ellenállásán megbukott, így csupán a fogyasztóvédelem ${ }^{17} \mathrm{olvadt}$ be a kvázi kormányhivatalba. A dekoncentrált szervek száma viszont továbbra sem csökkent.

A kőzépszint 1996 második félévétől új szereplővel bővưlt, miután a megyei területfejlesztési tanácsok létrejôttek ${ }^{18}$. Az állam és a gazdaság képviselöiből, valamint az önkormányzatok delegátusaiból álló tanácsok, ha korlátozottan is, de forráselosztó illetve stratégiaalkotó szerephez jutottak, ami a testület felértékelödését eredményezte a megyei közgyưlésekkel szemben.

A teruletfejlesztés új típusú rendszerének kiépülésével párhuzamosan felerősödött a régió-szervezés kérdése Magyarországon (Zongor 1998). A központi hatalom az Európai Uniós tárgyalásokra, illetve elvárásokra hivatkozva eröltette a regionális szervezödések létrehozatalát. Így szolid kormányzati erőszak nyomására jöttek létre az ún. tervezési-statisztikai régiók valamint szervezeteik, a regionális fejlesztési tanácsok. A megyei terulletfejlesztési tanácsok által létrehozott testületekben már a delegátusok delegátusai jelentek meg, illetve jelentős létszámban a minisztériumok képviselöi. A regionális fejlesztési tanácsok szakmai infrastruktúrája meglehetősen későn és vérszegényen alakult ki, így érdemi tevékenységlik ma még elég gyenge.

Mindenesetre egyértelmüvé vált, hogy a kormányzati hatáskörök és leginkább a pénzek nem juthatnak az erős legitimációjú megyei onnkormányzatokhoz, csak a regionális szervezódésekhez. Ennek a logikának megfelelően hozták létre az ún. regionális idegenforgalmi bizottságokat is ${ }^{19}$.

Az 1998-as parlamenti választásokat kővetően továbbra is nagy erőkkel folytatódott a közigazgatás szervezeti átalakítása és a regionalizálás. Ma már napirenden van a politikai-közigazgatási régió alakitásának kérdése is.

\section{A mai magyar közigazgatás állapotáról}

A kőzépszintú közigazgatás jelen helyzetének vizsgálatakor nem lehet eltekinteni a mai magyar kőzigazgatás egészének állapotától. A középszint problematikájának megértéséhez figyelembe kell venni az országos folyamatokat éppúgy, mint a települési önkormányzatok helyzetét. 
A rendszerváltást követö magyar közigazgatási struktúra alapvető jellemzője a széttagoltság. A helyi önkormányzatokról szóló törvény a települési önkormányzat közigazgatási feladatainak ellátására szervezett polgármesteri hivatal létesítési feltételeinél hihetetlenül megengedő módon szabályozza a kérdést ${ }^{20}$. A képesítési feltételeknek megfelelö jegyzö léte ugyanis még önmagában nem nyújt garanciát a kielégítő színvonalú közigazgatási jogszolgáltatásra. A települések felfokozott önállósulási törekvése az önálló hivatal iránti igénnyel egyuitt járt, melynek következtében az önálló jegyzőségek száma rövid idön belül duplájára növekedett, és nem ritka az olyan néhány száz lakosú telepủlés sem, ahol - a község költségvetésének jelentős részét ugyan felemésztve - önálló hivatal müködik. Gyakori, hogy a települések huzamos ideig jegyző nélkül maradnak, illetve felmentéssel még megfelelö végzettség nélküli (a szứkséges tanulmányait folytató) jegyzőt bíznak meg a feladatok ellátásával.

Jelenleg a települési önkormányzatok feladat- és hatásköre jórészt azonos, melynek színvonalas, törvényes és hatékony megvalósítása megfelelö szakmai ismereteket és a közigazgatásban szerzett gyakorlatot igényelne. A változó világ követelményeinek megfelelően egyre fontosabbá válik a jegyző innovatív készsége is, tekintettel arra, hogy az adott település képes legyen felkészüllten versenyezni a külsö támogatási forrásokért vívott harcban.

Természetesen egy közigazgatási szervezet szakmai működőképességét önmagában nem határozza meg a vezető felkészültsége, szưkség van megfelelő számú és színvonalú szakapparátusra is. Jelenleg hiába nött meg elsődlegesen a helyi igazgatásban dolgozók száma, mégis elmondható, hogy megfeleló színvonalú szakemberbỏl jelentős a hiány. Ez a hiány érvényes a közigazgatás valamennyi szintjére (minisztériumok, régiók, megyék, kistérségek és települések) és szervezetére egyaránt.

A látható és érzékelhető hiány ellenére most már egy évtizede nincs megoldva $a$ közigazgatási dolgozók szervezett képzése és továbbképzése. Ezt a hiányt nem tudják pótolni a zömében téritést igénylö konferenciák és magánképzések. Ebböl adódóan az egyes közigazgatási egységekben dolgozók szakmai felkészültsége és színvonala jelentős mértékben eltér egymástól, miközben az utánpótlás kérdése csaknem teljesen véletlenszerü. Általánosan érvényes, hogy a magyar köztisztviselői kar anyagi és társadalmi megbecsúlése folyamatosan várat magára. Az egymást váltó kormányok mindig meghirdetik a kisebb létszámú, hatékonyabb, de jobban megfizetett közigazgatást, amiből rendszeresen csak az anyagi elismerés hiánya marad meg. A szakmai előmeneteli rendszer csupán elvi lehetőség maradt, gyakorlatilag a karrier-rendszer nem müködik.

Megszakadt a szakmai együttmüködés a polgármesteri hivatali alkalmazottak és a megyei közigazgatási szervezetek munkatársai között, amely egyrészt abból adódott, hogy a megyei önkormányzat és hivatala teljesen mellérendelt kapcsolatba került a telepúlésekkel, másrészt a köztársasági megbizotti (majd a közigazgatási) hivatal tevékenységében az elözetes segitségnyújtás helyett az utólagos beavatkozás elve vált az uralkodóvá. E hivatalok túlzott hivatalnoki szemléletének kialakulásában 
jelentős szerepet játszott az indokolatlan pénzhiány, vagyis az a kormányzati elvárás, mely szerint a megyei közigazgatás törvényességének legföbb biztosítékát jelentő szervezetnek is jelentős bevételt kell teljesitenie müködöképessége fenntartása érdekében. Ez a kényszerhelyzet azt eredményezte, hogy e hivatalok nem - vagy nem a kelló mértékben és időben - nyújtanak segítséget a sok tekintetben felkészületlen önkormányzati hivataloknak és azok elszigetelten tevékenykedő munkatársainak.

Sajnálatos módon nincs élö kapcsolatrendszer a városi és a vonzáskörzetébe tartozó települések önkormányzati szakmai munkatársai között sem. A szakmai együttmúködés esetlegessége nehezíti a telepuulésközi kapcsolatok fejlődését is. A városkörnyéki igazgatási rendszer részleges, kimondatlan bevezetésének elemei fellelhetők a gyámügyi és építésügyi igazgatás legújabb szervezeti felépítésében ${ }^{21}$, ahol is egyes, városokba telepített szakigazgatási szervek a városkörnyék területén rendelkeznek illetékességgel. Ezen a két fontos területen a szakma elsődlegessége győzedelmeskedett a látszólagos települési érdek felett. A szakmai együttmüködés hiánya nehezíti a településközi kapcsolatok fejlődését egyéb területen is. Kistérségre szervezett közigazgatás kialakulásának alapfeltétele lenne a térségi szemlélettel és térségfejlesztési ismeretekkel rendelkező szakmai apparátus léte is, erről azonban ma még nem beszélhetünk. Ugyancsak nincs megfelelö ismeretünk az egyes kistérségek közigazgatási ügyeinek típusairól és azok gyakoriságáról. A városközpontú kistérség közigazgatási egységként való megjelenése átfogó gyakorlati elemzést igényel a különféle településszerkezetủ megyékben.

A közigazgatási egységek létszámának - elsỏdlegesen települési szintü - növekedése nem jár(hatot)t a szakmai minőség megtartásával, melynek következtében $a$ közigazgatási jogszolgáltatás szinvonala csökkent, és jelentősen eltér egy-egy közigazgatási egységnél. Emellett a jelenlegi önkormányzati és közigazgatási feladatok jelentős részénél nincs egyértelmủen rögzítve a közigazgatási szolgáltatási minimum követelménye. Az ágazati közszolgáltatások egy-egy átfogó területének szervezésére vonatkozó legújabb törvények ${ }^{22}$ már meghatározzák a fenntartók számára a szolgáltatási minimumot, viszont ez a szempontrendszer nem jelenik meg a közigazgatás szélesebb körében. A mai magyar közigazgatás filozófiájában nem igazán lehet felfedezni, hogy Magyarország - vitatható jelzősszerkezetü, de mindenképpen - piacgazdaság. A közigazgatásra vonatkozó müködési és döntéshozatali szabályok még mindig az alattvalói szemléletböl indulnak ki, ezt a változatlanságot jól jelzi, hogy még mindig hatályban van - ugyan többszöri módositásokkal - az államigazgatási eljárásról szóló 1957. évi IV. törvény.

A tơrvényhozó nem csupán az állampolgárokat tekinti kiskorúaknak, hanem magát a közigazgatást is. Így annak ellenére, hogy túl vagyunk a harmadik parlamenti illetve helyhatósági választáson a pártpolitika napi befolyásolási igénye a közigazgatással szemben jelentősen növekedett, melynek következtében lényegesen csökkent - az amúgy is szétzilált - igazgatási szervezetrendszer stabilitása. A köztisztviselők stabilitása sem telepulési, sem terulleti, sem országos szinten nincs biztosítva a politikával szemben. A közigazgatás és a politika szoros egymásra hatása természe- 
tes, viszont a müködés stabilitását és szakszerüségét, olykor törvényességét veszélyezteti, ha a szakmai szervezet nincs biztonságban és megfelelöen védve a napi politikától és annak ,ügyintézői szándékaitól”. A jegyzők politikai szempontú kiszolgáltatottsága elsődlegesen a pártelvú választási elven müködö - tízezer lakosnál nagyobb népességü - városoknál figyelhető meg egyértelmúen. Ugyanakkor valamennyi településen kódolva van a polgármester (képviselö-testület) és a jegyzö közötti konfliktus is azáltal, hogy évek óta folyamatosan növekszik a jegyzökhöz telepített államigazgatási hatáskörök és feladatok száma - megfelelö állami anyagi támogatás nélkül - melyek elvárható színvonalú ellátása elvonja az eröt a helyi közügyek és a testületek által megfogalmazott feladatok ellátásától.

A közigazgatás társadalmi nyilvánossága és ellenốrzése látszólag megoldott. Települési szinten a közigazgatás feletti társadalmi kontroll alapvetően a helyi nyilvánosság állapotától fuigg. A települési ügyek egyik érzékeny területe a szociális segélyezés, e hatósági ügytípust a törvényhozó teljesen indokolatlanul a képviselötestulethez telepitette, így a jogorvoslás lehetősége kikerült az igazgatás rendszeréböl és közvetlenül birói útra terelödött, ami viszont gyakorlatilag kizárt, mivel a ténylegesen rászorultak és elesettek nem fordulnak a bírósághoz jogorvoslatért, inkább elviselik a helyi megaláztatást és elutasitást. A középszinten müködő államigazgatási szervek tevékenységének társadalmi kontrollja gyakorlatilag megoldatlan. Ezen szervezetek kormányzati függősége egyértelmü, miközben tevékenységük helyi, megyei értékelésére alig van mód.

Nem megnyugtató az önkormányzatok és a közigazgatási szervek feletti törvényességi kontroll jelenlegi rendszere sem, egyre nyilvánvalóbban hiányzik az önálló közigazgatási birósági szervezet. A túlzsúfolt bírósági szervezetben a közigazgatási bíráskodás képtelen a valóságos életviszonyokhoz igazodó döntési rendszert kialakítani, aminek következtében leértékelödik a hatósági tevékenység hitele és eredményessége.

Az elözőekben jelzett jellemzők érvényesek a középszint szereplöire is. Ezen túlmenően strukturális szempontból egyre erőteljesebb az a kormányzati szándék, amely a középszint megyei kereteinek felbontására törekszik két irányból is. Egyfelöl a regionális szerveződések kialakításával kívánják megakadályozni a megyei önkormányzatok valódi területi önkormányzattá válását, egyben az államigazgatási feladatok regionalizálásával a megyei közigazgatási szervezeti rendszer kiüresítésére is törekszenek. Másfelöl a kistérség, mint közigazgatási szervezeti egység kialakításával alulról kivánják lebontani a megyét, miközben ez a települések feladat- és hatáskörének az elszivását is jelentené. A középszintủ közigazgatás jellemzője a különféle kvázi közigazgatási szerveződés jelenléte, gondolok itt többek között a területfejlesztési, valamint a munkaügyi tanácsokra, a megyei egészségügyi egyeztetö fórumra, avagy a regionális idegenforgalmi bizottságokra. A jelenlegi helyzetben középszinten a szervezetek sokasága révén már nem is beszélhetünk rendszerröl, inkább áttekinthetetlen rendszertelenségröl, avagy középszinttelenségról. 
A középszintü közszolgáltató intézmények általános fenntartójának tekinthető megyei önkormányzatok két oldalról is korlátok között látják el feladataikat. Egyrészt az intézmény székhelye szerinti települési önkormányzatok rendelkeznek a létesítmények tulajdonjogával, miközben tulajdonosi kötelmeiknek nem mindig kívánnak megfelelni. Másrészt a szakmai irányítás és felügyelet joga a megyei államigazgatási szervek joga, ami nehezíti, illetve kiüresíti a fenntartói jogosítványokat. A kórházak tekintetében ez a helyzet még tovább bonyolódik a finanszírozó társadalombiztosítóval.

Mindezekre tekintettel joggal állítható, hogy a magyar közigazgatás általános színvonala és társadalmi elfogadottsága folyamatosan gyengül és egyre gyengébb. A kơzépszintủ közigazgatás helyzetének tartós rendezetlensége tovább gyengíti a magyar igazgatás állapotát, és lassan veszélyezteti az ország Európai Uniós csatlakozási esélyeit is.

\section{Hogyan tovább?}

A magyar közigazgatást szelvẻnyeiben nem lehet átalakítani, a valódi reform strukturális bủvészmutatványokkal nem pótolható. Elengedhetetlenül szükség van a közigazgatási (állami és önkormányzati) rendszer átfogó áttekintésére és részletes elemzésére müködési és hatékonysági szempontból. A valóság tényleges megismerése nélkul csak látszattevékenységröl beszélhetünk.

Az átalakitás során figyelembeveendő, hogy az alapvető kőzigazgatási szolgáltatásokat az állampolgár számára lehetỏleg a lakóhelyén vagy elérhető közelségben kell biztositani. Ennek az elvnek érvényesülnie kell a másodfokú államigazgatási eljárás során is. (A jelenleg megyei szinten végzett másodfokú eljárás regionalizálása az ügyfelek számára hátránnyal járna.) Ugyanakkor a feladatok telepitése esetén meg kell vizsgálni, hogy a közigazgatási szerv rendelkezik-e megfelelő szervezeti, személyi, szakmai, technikai ellátási képességgel. Annak eldöntésénél, hogy állami avagy önkormányzati szerv lássa-e el az adott feladatot, figyelembe sziikséges venni a közigazgatási szerv szakmai és társadalmi felügyeletét.

Jelenleg az önkormányzati igazgatási szervek gyakran kapnak úgy feladatokat, hogy nem rendelkeznek a feladatellátáshoz szükséges feltételekkel, ugyanakkor az állami dekoncentrált szervek rendszere felett egyáltalán nem biztosított a társadalmi kontroll. A dekoncentrált szervek jelentős részét önkormányzati felügyelet alá lehetne helyezni, miközben biztosítható lenne e szervek tevékenységének szakmaisága.

A telepuilési és országos érdektöl eltérö sajátos térségi érdek létezését a jogalkotás szintjén is szükséges elismerni és elismertetni, melynek tartalmi összetevőire és lényegére a területrendezési tervek kérdésében az Alkotmánybíróság megfelelően rámutatott ${ }^{23}$. Emellett indokolt felülvizsgálni azt a rendszerváltó politikai jelszót is, mely szerint a telepủlések védelme és önállósága érdekében a megyei önkormányzatok pénzt ne oszthassanak. Ez a végig nem gondolt kizáró szabály gyakorlatilag feloldódott a megyei területfejlesztési tanácsok tényleges tevékenységével, noha e testületek legitimitása összehasonlíthatatlanul gyengébb, mint a választott megye- 
gyüléseké. Meggyőződésem szerint az ország érdeke, hogy müködöképes, az európai régiók tartalmi és fogalmi követelményeinek megfelelö területi önkormányzatok tevékenykedjenek Magyarországon. Ehhez viszont teljességgel fölösleges újabb struktúrákban és szervezetekben gondolkodni, hanem a megyét, mint létezö , jzigazgatási egységet indokolt valódi területi önkormányzattá fejleszteni, amely elsödleges szervezö erejévé válhat a megyén belüli térségfejlesztésnek valamint a nagytérségi, megyeközi kapcsolatoknak, azaz a tényleges regionális együttmüködésnek.

Az Európa Tanács által elfogadott régió fogalomnak ${ }^{24}$ a magyar megyék csaknem teljes mértékben megfelelnek, jószerivel csak az adókivetés joga illetve az adómegosztás kérdésében hiányzik a megfelelö magyar jogi szabályozás. Ezzel szemben a tervezési-statisztikai régiók valódi regionális önkormányzatokká fejlesztésének feltételei egyáltalán nincsenek meg. A magyar regionalizáció folyamata érdemivé válhatna, ha erős megyei területi önkormányzatok léteznének. Ehhez azonban $a$ szubszidiaritás elvét nem csupán a települések irányából kellene lehetővé tenni a megyék felé, hanem a központi kormányzati feladatok és hatáskörök tekintetében is. A tényleges decentralizáció nélkül a térségi folyamatok esetlegessé válnak, és a települések valamint a településközösségek fejlesztési érdekei is tovább sérülnek.

A magyar közigazgatási szintek - vagyis a telepúlési, a megyei és a központi szint - belátható időn belül nem fognak megváltozni, még akkor sem, ha megjelenik a kistérség, mint igazgatási és térségszervező kategória, valamint kialakulnak müködőképes regionális egyuittmüködések is. A megye „alatt” és „fölött” kialakuló együttmúködési szintek akkor és annyiban lesznek képesek közigazgatási szerepet betölteni, amennyiben a saját hatáskörrel rendelkezö települések illetve megyék ezeket a szervezödéseket erre felhatalmazzák. Ứj szervezetek lázas építése helyett a meglévők müködöképességének fokozásával érhetünk csak célba, mivel az európai integrációra való felkészillésünk már így is elkésett. Örökös átalakitási, bizonytalansági folyamatban a közigazgatás nem lesz képes feladatát megfelelö szinten ellátni, ezért a rendszer stabilitására kellene törekedni.

\section{Jegyzetek}

1 A tanácsokról szóló 1971. évi I. tôrvény részét kénęte annak a tervezett ṇlitikai reformrcnmagnak, amely hivatott lett volna társadalompolitikai oldalról segíteni az 1968-ban bevezetett ún. új gazdasági mechanizmust. A politikai reformot a Szovjetunió nem engedélyezte a Csehszlovákiába tơrtént bevonulást követően, igy a harmadik tanácstörvény csak tơredékesen és jelzésszerüen nyitott a helyi ơnállóság felé. A tanácsok jellegének meghatározásába (Tt. 2 . § [1] bekezdés) a szocialista táborban egyedulálló módon bekerült az ơnkormányzatiság fogalma mindenféle érdemi tartalmi kibontás nélkủl.

2

${ }^{3}$ Lásd: Tt. 69/A. §

${ }^{4}$ Lásd: Tt. 69/B. §-át, valamint az eloljáróságokról szóló 9/1985. (IIl.7.) Mt. rendeletét, melyben már megjelenik, hogy az elöljáróság a nem székhely társkơzség lakosságának népképviseleti - onkormányzati testulete.

${ }^{5}$ Lásd: az országos telepuléshálózat-fejlesztési koncepcióról szóló 1007/1971. (II. 16.) Korm. határozatot.

${ }^{6}$ Ekkor buktak meg nyilvánosan és véglegesen Borsod-Abaúj-Zemplén, Csongrád, Györ-Moson-Sopron és Veszprém megyék elhíresült volt MSZMP megyei első titkárai. 
${ }^{7}$ A megyei tanácsigazgatási rendszer átalakításában élen járt Somogy megye, az akkori megyei tanácselnök, Dr. Gyenesei István vezetésével. A Somogy megyei példa hatására szelíd kőzponti és politikai nyomás eredményeként a megyei szakigazgatási struktúra széttagolt rendszere helyett osszevont és erős egységek jöttek létre némi létszámcsökkentéssel.

${ }^{8}$ Az Országgyúlés 1990. augusztus 3-ai ulésnapján tơbb mint $90 \%$-os tơbbséggel fogadta el a helyi ơnkormányzatokról szóló 1990. évi LXV. tơrvényt, amely az onkormányzati képviseló-testuletek tagjai választásának napján, szeptember 30-án lépett hatályba.

9 Az 1991. évi XX. tv., az ún. hatásköri tơrvény viszonylag késön - 1991. július 23-án - lépett hatályba, és meglehetősen formálisan rendezte a hajdan volt tanácsigazgatási feladatokat az új szereplők kőzőtt.

${ }^{10}$ Az Alkotmány 44/A. § (1) d) pontja kimondja: „A helyi képviselö-testulet a tơrvény keretei közőtt megállapítja a helyi adók fajtáit és mértékét."

11 Az 1990-es önkormányzati tơrvény a megyei jogú várossá nyilvánitás egyetlen feltételeként - a képvise16-testulet kérelme esetén - ottvenezemél nagyobb lakosságszámot írt elob. Mint ismeretes az eredeti százezer lakos helyett dr. Szájer József soproni képviselö javaslata alapján csőkkentették le a számot, hogy ezáltal lehetövé tegyék tőbbek között a nem megyeszékhely városok megyén kívuliségét is.

12 Lásd: A helyi ơnkormányzatokról szóló 1990. évi LXV. törvény 98-100. §-ait, valamint a köztársasági megbízott jogállásáról, hivataláról és egyes feladatairól szóló 1990. évi XC. Tơrvényt.

${ }^{13}$ A volt megyei tanácsi szakigazgatási szervek feladatát részben vagy egészben átvevő dekoncentrált szervek létrejottének időbeli folyamata a kővetkezö:

február 1.: Teruleti Államháztartási és Kozigazgatási Információs Szolgálat (19/1991-es Korm. rendelet) március 1.: Megyei munkauggyi kơzpont (1991. évi IV. tv.)

április 1.: Megyei foldmúvelésugyi hivatal (1991. évi VII. tv.)

április 9.: Állami Népegészséguggyi és Tisztiorvosi Szolgálat (1991. évi XI. tv.)

július 29.: Megyei fogyasztóvédelmi felügyelőség (95/1991. (VII.23.) Korm. rend.)

augusztus I.: Megyei közlekedési felügyelet 94/1991.(VII.23.) Korm. rend.)

január I.: Megyei sportigazgatóság (18/1991. (XI.22.) MKM rend.)

szeptember 1.: Regionális oktatási kơzpont (Tájékoztató Müvelödésügyi Kozlonny 17. számában)

december 12.: Teruleti fóépítészeti hivatalról (2I/1992. (XII.4.) KTM rend.)

14

A sportról szóló 1996. évi LXIV. tơrvény 1997. január 1-jével a sportigazgatási feladatokat a megyei ठnkormányzat feladatává tette, de még egy esztendőn keresztul a szervezetet megállapodás alapján az OTSH finanszírozta.

15 Az onkormányzati tơrvény módosítása (1994. évi LXIII. tv.) sajátos módon a megyei ơnkormányzat fejezetben jeleníti meg a megyei területfejlesztési tanácsot. Ötv. 70. § (3) bek.: „A teruletfejlesztési feladatok, illetőleg a kormányzati területi fejlesztési programok ơsszehangolását - kủlơn törvényben megállapított feladatkőrben és szervezetben - a megyei teruletfejlesztési tanács végzi." A létrehozásáról az Ötv. 115 . § (4) bekezdése rendelkezik: „A 70. § (3) bekezdése szerinti megyei terulletfejlesztési tanács a teruletfejlesztésröl szóló tơrvény rendelkezései szerint, de legkésőbb 1995. jủnius 30-ig jön létre."

${ }^{16} \mathrm{Az}$ Ötv. 61. § (1) bekezđése 1994-es kiegészitése révén valamennyi megyeszékhely város megyei jogú város. Így nyerte el ezt címet Salgótarján és Szekszárd. Így most 18 megyeszékhely (Pest megye székhelye Budapest), valamint 4 megyei „nagyváros” (Dunaújváros, Hódmezövásárhely, Nagykanizsa és Sopron) alkotják a megyei jogúak csapatát, valamint az Ötv. 61/A. §-a intézményesítette az egyeztető bizottságot.

${ }^{17}$ Lásd: A kőzigazgatás reformjáról szóló 1100/1996. (X.2.) Korm. határozatot, valamint a Fogyasztóvédelmi Felugyelóségról szóló 95/1991. (VII.23.) Korm. rendelet módositásáról szóló 199/1996. (XII.22.) Korm. rendeletet.

${ }^{18}$ Lásd: A területfejlesztésrôl és rendezésről szóló 1996. évi XXI. tơrvényt.

${ }^{19}$ Lásd: az 1007/1998. (I.23.) Korm. határozatot az idegenforgalom teruleti irányitásának korszerüsitéséröl.

${ }^{20} \mathrm{Az}$ Ötv. 39. § (2) bekezdése a kővetkezöt mondja: „Az ezernél kevesebb lakosú kőzség képviselర̈testülete is létrehozhat ơnálló hivatalt, ha a képesítési kơvetelményeknek megfelelö jegyzőt nevez ki."

21 Lásd: a gyámhatóságokról, valamint a gyermekvédelmi és gyámügyi eljárásról szóló 149/1997. (IX.10.) Korm. rendeletet, továbbá a kiemelt építésügyi igazgatási ugyekben eljáró hatóságok illetékességi teruletéről, a kijelőlési eljárásról, valamint a szakmai feltételekről szóló 220/1997. (XII.5.) Korm. rendeletet. 
22

Lásd: a gyermekek védelméröl és a gyámugyi eljárásról szóló 1997. évi XXXI. toorvényt; a szociális igazgatásról és szociális ellátásokról szóló 1993. évi III. tơrvény módosításáról szóló I997. évi LXXXIV. tơrvényt; a közoktatásról szóló 1993. évi LXXIX. toorvény módosításáról szóló 1997. évi CXXVIII. tơrvényt; a kulturális javak védelméről és a muzeális intézményekről, a nyilvános könyvtári ellátásról és a kőzmúvelődésről szóló 1997. évi CXL. tơrvényt.

23

Az Alkotmánybiróság 3/1997. (1.20.) ẢB határozata tőbbek között leszögezi: „Az Alkotmány idézett rendelkezése - a helyi ơnkormányzatok alapjogai (44/A. \$) egyenlök - ugyanis nem akadálya annak, hogy bizonyos tárgykörben a törvény a teruleti onkormányzathoz telepítse a feladatot és a hozzá kapcsolódó szabályozási jogkơrt, illetöleg azt - meghatározott munkamegosztás szerint - részben a teruleti, részben pedig a telepúlési onkormányzattal megossza. Mindkét fajta hatáskőr telepítésnek az a szúkségképpeni következménye, hogy a telepullési ónkormányzat rendelete nem állhat ellentétben a teruleti onkormányzat rendeletével."

24 Lásd: A Regionális Ơnkormányzatok Európai Chartáját (Az Európai Tanács anyaga 1997).

\section{Irodalom}

Zongor G. (1984a) Járás - városkörnyék - kőrzet. - Mühely. 2. 59-66. o.

Zongor G. (1984b) Két-és félfokú közigazgatás. - Figyelö. szeptember 20. 7. o.

Zongor G.(1990) Tơrvény-betúje, vagy szelleme szerint. -Figyelô. február 15. 4. o.

Zongor G. (1991) Adalékok a megyei közgyülések kialakitásáról és osszetételéröl. - Comitatus. 5. 56-64. 0 .

Zongor G. (1996) A megyei kỏzgylúlések választása és ôsszetétele. - Társadalmi Szemle. 2. 69-79. o.

Zongor G. (1998) Kis magyar regionalizáció, avagy miért nem mükődik az, aminek mükődni kellene? Comitatus. 7-8. 53-63. o.

\section{VARIATIONS FOR INTERMEDIATE LEVEL OR THE LACK OF HUNGARIAN INTERMEDIATE LEVEL}

\section{GÁBOR ZONGOR}

After the change of regime the main characteristic of the Hungarian administration structure is its dividing. The law of local governments has lead to one of the most important and most exciting changes in the process of change of political system. The primary aim of the legislation was the "liberation" of settlements, and in connection with the issue of intermediate level it concentrated to reach a compromise to eliminate the different views, instead of examining its operability. Functions and tasks of county governments were defined generally, but it become fairly clear from the regulation that function of new type county governments - with the one-sided overstatement of the principle of subsidiarity - has limited to the maintaining of institutions are providing public services. Central government has forced the foundation of regional organisation only due to negotiations with and expectations of the European Union. So the so-called planning-statistical regions and its organisations the regional development councils - have been established in the pressure of solid govermmental force. Professional infrastructure of regional development councils has been formed very late and enervate, therefore its real activity is quite poor yet. 
There is an attempt to demolish the counties with the establishment of subregions, as administration units. The several quasi-administrational organisations are the characteristics of intermediate level administration, like organisations of regional development, labour councils, county health conciliation forum, regional committee of tourism. Under present circumstances due to the crowd of different organisations in the intermediate level we can't say from system rather the lack of system and the lack of intermediate level. 